\title{
Turf algae-mediated coral damage in coastal reefs of Belize, Central America
}

Many coral reefs in the Caribbean experienced substantial changes in their benthic community composition during the last decades, resulting in a shift from scleractinian corals to other benthic invertebrate and algae dominance and consequent degradation of coral reefs, but knowledge about how the related role of coral-algae contacts may negatively affect corals is scarce. Therefore, benthic community composition, abundance of algae grazers, and the abundance and character of coral-algae contacts were assessed in situ at 13 Belizean reef sites distributed along a distance gradient to the Belizean mainland $(12-70 \mathrm{~km})$ : Mesoamerican Barrier Reef (inshore), Turneffe Atoll (inner and outer midshore), and Lighthouse Reef (offshore). In-situ surveys revealed significantly higher benthic cover by scleractinian corals at the remote Lighthouse Reef $(26-29 \%)$ when compared to the other sites (4 - $19 \%$ ). The abundance of herbivorous fish and the sea urchin Diadema antillarum significantly increased towards the offshore reef sites, while the occurrence of direct coralalgae contacts consequently increased significantly with decreasing distance to shore. About $60 \%$ of these algae contacts were harmful (exhibiting coral tissue damage, pigmentation change, or overgrowth) for corals (mainly genera Orbicella and Agaricia), particularly when filamentous turf algae were involved. These findings provide support to the theory that (turf) algae-mediated coral damage occurs in Belizean coastal, near-shore coral reefs. 


\section{Turf algae-mediated coral damage in coastal reefs of Belize, Central America}

2 Christian Wild ${ }^{1 *}$, Carin Jantzen ${ }^{2}$, Stephan Georg Kremb ${ }^{3}$

$3{ }^{1}$ Coral Reef Ecology Group (CORE), Leibniz Center for Tropical Marine Ecology (ZMT),

4 Fahrenheitstr. 6, 28359 Bremen, Germany

$5 \quad{ }^{2}$ SECORE Media \& Communication, Bremen, Germany

$6{ }^{3}$ King Abdullah University of Science and Technology, Thuwal, 23955 -6900, Kingdom of Saudi

7 Arabia

8 *corresponding author, E-mail: christian.wild@zmt-bremen.de

\section{ABSTRACT}


10 Many coral reefs in the Caribbean experienced substantial changes in their benthic community

11 composition during the last decades. This often resulted in phase shifts from scleractinian coral

12 dominance to that by other benthic invertebrate or algae However, knowledge about how the

13 related role of coral-algae contacts may negatively affect corals is scarce. Therefore, benthic

14 community composition, abundance of algae grazers, and the abundance and character of coral-

15 algae contacts were assessed in situ at 13 Belizean reef sites distributed along a distance gradient 16 to the Belizean mainland (12-70 km): Mesoamerican Barrier Reef (inshore), Turneffe Atoll (inner

17 and outer midshore), and Lighthouse Reef (offshore). In-situ surveys revealed significantly

18 higher benthic cover by scleractinian corals at the remote Lighthouse Reef (26- $29 \%)$ when 19 compared to the other sites (4 - $19 \%)$. The abundance of herbivorous fish and the sea urchin 20 Diadema antillarum significantly increased towards the offshore reef sites, while the occurrence

21 of direct coral-algae contacts consequently increased significantly with decreasing distance to 22 shore. About $60 \%$ of these algae contacts were harmful (exhibiting coral tissue damage, 23 pigmentation change, or overgrowth) for corals (mainly genera Orbicella and Agaricia), 24 particularly when filamentous turf algae were involved. These findings provide support to the 25 hypothesis that (turf) algae-mediated coral damage occurs in Belizean coastal, near-shore coral 26 reefs.

27

28 Keywords: coral reef ecology, phase shift, coral algae contacts, coastal influence

\section{INTRODUCTION}

30 Phase shifts from scleractinian corals to other invertebrates such as sponges (Maliao et al. 2008), 31 ascidians (Bak et al. 1996) or octocorals along with a strong increase in occurrence of benthic 32 algae and cyanobacteria (Hughes 1996; Gardner et al. 2003; Andrefouet and Guzman 2005) are 
33 widely reported from coral reefs in the Caribbean Sea (Hughes 1994; Gardner et al. 2003). These

34 reefs are highly affected by intense tourism, overfishing and coastal agriculture (Burke and 35 Maidens 2004), but also by a wide diversity of severe coral diseases (Goreau et al. 1998; Aronson 36 and Precht 2001; Patterson et al. 2001), and a previous pathogen-induced mass mortality of the 37 sea urchin Diadema spec. (Lessios et al. 1984), the formerly dominant herbivorous invertebrate 38 in Caribbean reefs.

39 In contrast, Caribbean coral reefs off Belize, Central America, have been described as pristine 40 and undisturbed compared to reef locations in the Northern Caribbean (Lapointe et al. 1997), 41 which was mainly attributed to low fishing pressure in Belize waters and a modest development 42 of coastal agriculture and tourist industry. However, McClanahan and Muthiga (1998) and 43 McClanahan et al. (1999) reported benthic community shifts from corals to fleshy macroalgae at 44 reef locations along the Belizean Barrier Reef and Glovers Atoll off Belize, although fishing and 45 inorganic nutrient concentrations were at relatively low levels. Thus, there is some debate about 46 the degradation status of Belizean coral reefs and the particular role of benthic algae that can 47 damage corals if they are in direct contact to each other (Smith et al. 2006; Haas et al. 2010a).

48 Many benthic algae (Hay et al. 1987; Schmitt et al. 1995) and cyanobacteria (Nagle and Paul 49 1998) species produce toxic secondary metabolites that act as agents against herbivory and anti50 fouling (Paul et al. 2001) and therefore may negatively affect corals. Additionally, abrasion51 mediated polyp retraction (River and Edmunds 2001) or high production of labile dissolved 52 organic matter (DOM) by reef algae, which can stimulate planktonic microbial metabolism with 53 ensuing $\mathrm{O}_{2}$ deficiency (Haas et al. 2010a; Haas et al. 2010b; Wild et al. 2010), may also 54 negatively affect corals in direct contact with algae. However, data about benthic community 55 composition in combination with assessments of coral-algae interactions in reefs off Belize have 56 not been described in the scientific literature. The objectives of the present rapid assessment in 57 situ study therefore were a) to estimate live coral and reef algae cover along with grazer (sea 
58 urchin Diadema antillarum and herbivorous fish) abundance, and b) to quantify and characterize

59 coral-algae contacts at different reef locations in 12 to $70 \mathrm{~km}$ distance from the Belizean

60 mainland. Main study hypothesis was that the abovementioned parameters are controlled by

61 distance to coast with associated potential top-down and bottom-up pressures.

62

\section{MATERIAL AND METHODS}

\section{Study site}

65 All surveys were carried out during a Belize expedition of the research and media vessel 66 Aldebaran between 12 and 23 March 2009. In total, 13 reef sites were investigated along a 67 distance gradient to the Belize mainland $(12-70 \mathrm{~km})$. Surveys were conducted at sites located 68 along the Mesoamerican Barrier Reef (inshore, $\mathrm{n}=4$ ), Turneffe Atoll (West side, i.e. inner 69 midshore, $\mathrm{n}=5$; East side, i.e. outer midshore, $\mathrm{n}=2$ ) and Lighthouse Reef (offshore, $\mathrm{n}=2$ ). 
70 Locations were mapped with GPS, and distances to Belize City were determined (Fig. 1 and 71 Table 1).

\section{Benthic cover}

73 At each site, two surveys (I. and II.) were carried out independently in water depths of $5-8 \mathrm{~m}$ by

74 SCUBA divers. I. During each of these surveys, two $50 \mathrm{~m}$ line point intercept transects (LPI) with

75 measuring points every $50 \mathrm{~cm}(\mathrm{n}=202$ data points) were conducted to assess benthic community

76 composition. Test transects were carried out prior to select appropriate categories for benthic

77 cover and were then defined as: all present scleractinian corals and benthic alga genera as well as

78 turf algae (which were defined as a dense conglomerate of various diminutive and filamentous

79 algae growing up to a height of about $1 \mathrm{~cm}$ ), hydrozoan fire corals, octocorals (soft corals and 80 gorgonians), sponges and seagrasses. According to Nadon and Stirling (2006), the conducted 81 transect methodology provides best combination of efficiency and accuracy.

\section{Herbivores abundances}

83 II. Herbivore abundance was measured in a $2 \mathrm{~m}$ wide and $50 \mathrm{~m}$ long belt, with the transect line in

84 the middle (resulting area $=100 \mathrm{~m}^{2}$ ). In this area, abundances of the sea urchin D. antillarum 85 were quantified along with numbers of key herbivorous fishes (parrot fishes, surgeon fishes and 86 chubs) in the water column up to $3 \mathrm{~m}$ above this area using the following categories: 1 . few $(\mathrm{n}=$ 87 1-5), 2. few-occasional $(\mathrm{n}=6-10), 3$, occasional $(\mathrm{n}=11-50), 4$. occasional-many $(\mathrm{n}=51-100), 5$. 88 many ( $\mathrm{r}>101)$. Photo documentation was used to verify taxonomic identification and to avoid 89 any observer bias.

\section{Coral-algae contacts}


91 Along with benthic cover, coral-algae contacts were recorded at each site in one LPI transect. All

92 scleractinian corals were carefully inspected for the occurrence of coral-algae contact, i.e. the 93 presence of macro or turf algae in direct contact to the coral. Coral-algae contacts were recorded

94 with photos, taken directly above the contact area using Panasonic LUMIX DMC-TZ5 and 95 Canon PowerShot G10 digital cameras (resolution: 7 and 14 mega pixels, respectively). 96 Subsequently, digital image analysis was used to identify both groups of organisms to the genus

97 level and to evaluate the character of coral-alga contacts.

98 The following categories were used: I. no visible impact on corals (Fig. 2 a), II. overgrowth by 99 algae (i.e. parts of the algae overbearing the interface between coral and algae and entering the 100 coral zone) leading to reduced light availability or even coral tissue damage (Fig. 2 b, c), III. 101 coral tissue pigmentation decrease at the interface (Fig. 2 d); categories II. \& III. were 102 considered as visibly harmful contact for corals.

\section{Statistical analyses}

104 Data were not normally distributed. Therefore, the two-sided Mann-Wilcox U-Test was 105 conducted for direct comparisons of parameters between the remote locations and the other sites, 106 both pooled for that purpose. All values are given as means \pm SE. The non-parametric Spearman 107 correlation test was applied to relate shore distance to a) benthic cover (coral and algae), b) 108 abundance of coral-algae contacts and c) D. antillarum occurrence. To check for correlation of 109 herbivorous fish abundances and distance from shore, their frequency was set as rank order and 110 the non-parametric Spearman correlation test was likewise conducted.

\section{RESULTS}

\section{Benthic cover and herbivores abundances}


113 Benthic cover by scleractinian corals was low $(4-19 \%)$ at all investigated coral reef locations

114 except at the remote Lighthouse Reef $(26-29 \%)$ where coral cover was significantly higher

115 compared to Turneffe Atoll and the Barrier Reef (two-sided U-test, p < 0.05) (Table 2 and Fig. 3).

116 Among the scleractinian corals, the genera Agaricia and Orbicella dominated (Table 2).

117 Specimens of the genus Acropora, namely A. cervicornis, were only observed at Lighthouse

118 Reef, and A. palmata was not found at any site. Scleractinian corals were the most abundant

119 benthic organisms only at the remote Lighthouse Reef. At eight other sites, algae dominated the 120 benthic community, and at the remaining three sites octocorals were dominant. Coral cover was

121 positively correlated with distance to shore (Table 3, non-parametric Spearman correlation, $\mathrm{p}<$ 122 0.05; Fig. 4).

123 Visible benthic sponge cover was relatively low with 2 - $12 \%$. Among the hydrozoans, only the

124 fire corals Millepora could be observed, but its contribution to benthic community was minor $(\leq$ $1255 \%$ benthic cover at all reef sites, if any present). The relative seafloor cover by benthic algae 126 was highly variable among sites (Table 2). Consequently, there were no significant differences in 127 algal cover between the three geographical groups of reef sites and no correlation along the 128 distance gradient to the Belizean mainland (Fig. 4). The calcareous green algal genus Halimeda 129 was the most abundant benthic algae at eight sites, but brown algae of the genus Dictyota, 130 filamentous turf algae consortia and fleshy red or brown algae (Jania, Wrangelia, Padina,

131 Lobophora) along with coralline red algae were also observed at all sites. Other green algae 132 (Udotea, Rhipocephalus) and seagrasses (Thalassia) could be detected only at three stations 133 along the Barrier Reef and at Southwest Turneffe Atoll.

134 Herbivorous fishes were most abundant (more than 100 individuals per $100 \mathrm{~m}^{2}$ reef area) at the 135 remote Lighthouse Reef, where also the only specimens of $D$. antillarum could be observed. This 136 coincided with lowest algal cover at the mentioned sites compared to all others (2-sided U-test, $p$ $137<0.05)$. 
138 By contrast, all other sites exhibited low (less than 50 individuals per $100 \mathrm{~m}^{2}$ reef area)

139 herbivorous fish abundances, and no D. antillarum was present (Table 3, Fig. 4).

\section{Abundance and character of coral-algae contacts}

141 Corals were often in direct contact with algae (10-78 \% of all corals observed), with significantly

142 higher percentage of contact at sites of the Mesoamerican Barrier Reef and the inner-midshore of

143 Turneffe Atoll (Table 2) compared to the more remote sites (2-sided U-test, $\mathrm{p}<0.01$ ). Coral-algae

144 contacts decreased with growing distance to shore (Table 3, non-parametric Spearman

145 correlation, $\mathrm{p}<0.01)$. The percentages of contacts that were visibly harmful for the corals,

146 including coral tissue damage, coral pigmentation change and overgrowth by algae, exhibited no

147 correlation with distance to the mainland, and were very variable (0 - $100 \%)$.

148 In total, 203 different coral-alga contacts were investigated and revealed that $18 \%$ of these

149 contacts involved more than one coral or algal genus. Among corals, the genera Orbicella and

150 Agaricia were most often involved in contacts with algae (31 and $29 \%$ respectively), whereas the

151 genera Porites and Siderastrea showed low relative involvement (10\% each). Filamentous turf

152 (30\%), fleshy red (24\%, particularly genus Jania), the brown alga Dictyota spp. (21\%) and the

153 green alga Halimeda spp. (19\%) together accounted for $94 \%$ of all algae representatives

154 involved in contact with corals.

155 Analysis of visibly harmful contacts revealed that on average among all sites $50 \%$ of the 156 scleractinian corals were overgrown by algae and $11 \%$ revealed pigmentation change, whereas 157 about $39 \%$ of all coral-algae contacts showed no visible effect on corals. Harmful contacts were 158 primarily caused by filamentous turf algae consortia (35\%) and to a minor extent by fleshy red 159 algae (30\%), the calcifying green algae Halimeda spp. (26\%) and the fleshy brown algae 160 Dictyota spp. (19 \%). Contact with Halimeda did only result in coral tissue pigmentation 161 decrease, but not in tissue damage. 


\section{DISCUSSION}

163 This study indicates negative impacts on benthic coral reef communities close to the Belize

164 mainland coast, manifested by rising coral-algae contact frequency and decreasing coral cover.

165 The results of the present study also indicate that there is a relationship between abundance of

166 herbivorous fish and abundance along with character of coral-alga contacts in Belizean reefs.

167 A crucial top down factor on reef degradation is the presence of herbivores, namely fish and sea

168 urchins (Hughes 1994, Lapointe 1997), and in the present study the abundance of herbivorous

169 fish decreased with decreasing distance to shore, while D. antillarum was only detected at the

170 remote study sites. Therefore, grazing of algae by both benthic and pelagic herbivores likely

171 contributes to shaping benthic community composition in the investigated reefs. Coral-algae

172 contact abundance, as an indicator for degradation of coral reefs, showed negative correlation

173 with herbivorous fish abundance. This suggests that a top-down scenario is involved in the algae-

174 mediated degradation of Belizean coral reefs. However, a potential simultaneous bottom-up co-

175 effect of coastal eutrophication cannot be excluded.

176 Herbivorous fish abundance was significantly higher at the remote reef sites (Lighthouse Long

177 Caye, Lighthouse Long Caye West and Turneffe NW). The study by Williams et al. (2001)

178 demonstrated that the presence of corals, i.e. their 3D-structure, attracts herbivorous fish. Coral

179 reef decline, when linked to low abundances of grazing fish, may thus represent a positive 
180 feedback situation. Additionally, spatial heterogeneity in herbivore abundance and therefore

181 grazing intensity may contribute to regional diversity among and within tropical reef habitats

182 (Lewis 1986), and fishes do likely play a major role in structuring coral reef macrophyte

183 communities (Morrison 1988; Reinthal and Macintyre 1994).

184 In the Caribbean, in addition to herbivorous fish, D. antillarum and other sea urchins control 185 benthic algae populations (Aronson et al. 2000, Aronson and Precht 2001, (McManus and 186 Polsenberg 2004). McClanahan and Muthiga (1998) reported that population density of $D$. 187 antillarum in Belizean reefs was less than 1 individual per $1000 \mathrm{~m}^{2} 14$ years after the die off in 188 1983-84. The present study showed that D. antillarum now occurs in actual numbers of 20 to 30 189 individuals per $1000 \mathrm{~m}^{2}$ at some reef locations off Belize, i.e. at least one order of magnitude 190 higher population density compared to about 10 years ago. These findings are supported by 191 observations of $D$. antillarum at other reef locations along the Barrier Reef and Turneffe Atoll 192 (M. McField, Smithsonian Institution Belize, pers. comm.) and is in agreement with other studies 193 that reported recovery of D. antillarum in reefs around Jamaica (Edmunds and Carpenter 2001) 194 and St. Croix (Miller et al. 2003). The findings of the present study indicate that combined 195 herbivory by only few fishes and sea urchins was not sufficient in order to prevent a large number 196 of coral-algae contacts particularly at reef sites close to the Belizean mainland.

197 The observed coral-algae contacts can be the cause for manifold threats triggered directly or 198 indirectly by algae in contact with corals. Overgrowth of coral tissue, tissue damage, and 199 pigmentation decrease occurred most often in contact with turf algae. Considerable tissue damage 200 caused by the turfing filamentous red alga Corallophila huysmansii on the branching 201 scleractinian coral Porites cylindrica was also observed by Jompa and McCook (2003a), which 202 may be related to allelochemical mechanisms. The delicate filaments of turf algae are likely able 203 to colonise and kill coral tissue by direct chemical effects as suggested by Jompa and McCook 204 (2003b). This assumption is supported by results from Titlyanov et al. (2007), who demonstrated 
205 that the cyanobacterium Lyngbya bouillonii, often associated with turf algae, acts as a poison 206 against scleractinian corals and is able to kill coral tissue. Turf algae can also trap organic matter

207 in their delicate branches (Stewart 1989), which was frequently observed in the present study.

208 Thus, while overgrowing coral colonies, turf algae may form dense algal-sediment mats causing a 209 localized smothering and shading of coral colonies (Nugues and Roberts 2003). This increases 210 energy expenditure for cleaning mechanisms and leads to a reduced energy acquisition due to

211 shading of photosynthetically active parts of the coral (Potts 1977). Additionally, the proximity of 212 macroalgae may further lead to the alteration of water flow, not only causing a change in the rate 213 of sedimentation (Eckman and Duggins 1991), but also an alteration in the rate of gas exchange 214 (Hurd and Stevens 1997) and an inhibition of particle capture rates of corals (Morrow and 215 Carpenter 2008). The combination of light reduction through shading, reduced gas exchange, a 216 decrease in nutrient supply through the inhibition of particle capture rates and increased energy 217 expenditure for cleaning mechanisms may weaken the competitive ability of corals. Weakened or 218 dead coral tissue may then be more easily overgrown by more persistent secondary settlers such 219 as fleshy red or brown algal species tightening the algal predominance following the first 220 invasion of the relatively short-lived turf algal assemblages. The result of the present study that

221 comparably less coral tissue damage was observed in direct contact with calcifying green algae of

222 the genus Halimeda may be explained by the morphology of these algae that in contrast to turf 223 and fleshy red algae do not exhibit such delicate filaments. However, Nugues et al. (2004)

224 reported that pigment decrease of corals in contact with Halimeda may be explained by the role 225 of this particular alga in introducing white plague disease to reef corals. This is confirmed by the

226 finding of the present study that most pigment decrease of coral tissue was associated with 227 Halimeda contacts.

228 The negative correlation between abundance of coral-algae contacts and occurrence of herbivores 229 in the investigated reefs may thus be a further piece of a puzzle supplementing recent studies 
230 (Stevenson et al. 2007; Sandin et al. 2008) that found negative correlation between coastal

231 pressures (overfishing, but also potentially simultaneous coastal eutrophication that was not

232 assessed in the present study) and coral reef health. The observed frequent contact with

233 (particularly turf) algae may cause considerable coral damage in coastal, near-shore reefs of

234 Belize.

\section{ACKNOWLEDGEMENTS}

236 We thank Dr. M. Mc Field and E. M. Zetsche for background information about Belize coral reefs 237 and their valuable advice prior to this study. S. Bendixen, S. Duewel, A. Wittenzellner, and 238 particularly captain F. Schweikert, are acknowledged for their help during the ALDEBARAN 239 cruise, and A. Haas and S. Becker are acknowledged for their help during data analysis and figure 240 preparation.

\section{FUNDING STATEMENT}

242 This research was funded by German Research Foundation (DFG) grant Wi 2677/2-1 to C.W and 243 ALDEBARAN Förderverein für Meeresforschung und Umweltjournalismus e.V.

\section{LITERATURE CITED}


245

246

247

248

249

250

251

252

253

254

255

256

257

258

259

260

261

262

263

264

265

266

267

268

269

270

271

272

273

274

275

276

277

278

279

280

281

282

283

284

285

286

287

288

289

290

291

292

293

Eckman JE, Duggins DO (1991) Life and death beneath macrophyte canopies: effects of understory kelps on growth rates and survival of marine benthic suspension feeders. . Oecologia 87: 473-487

Edmunds PJ, Carpenter RC (2001) Recovery of Diadema antillarum reduces macroalgal cover and increases abundance of juvenile corals on a Carribean reef. Proc Nat Acad Sci 98: 5067-5071

Haas AF, al-Zibdah M, Wild C (2010a) Seasonal in-situ monitoring of coral-algae interaction stability in fringing reefs of the Northern Red Sea Coral Reefs 29: 93-103

Haas AF, Naumann MS, Struck U, Mayr C, el-Zibdah M, Wild C (2010b) Organic matter release by coral reef associated benthic algae in the Northern Red Sea. J Exp Mar Biol Ecol 389: 53-60

Hay ME, Fenical W, Gustafson K (1987) Chemical defence against diverse coral-reef herbivores. Ecology 68: 1581-1591

Hurd CL, Stevens CL (1997) Flow simulation around single- and multiple-bladed seaweeds with various morphologies. J Phycol 33: 360-367

Jompa J, McCook L (2003a) Contrasting effects of turf algae on corals: massive Porites spp. are unaffected by mixed-species turfs, but killed by the red algae Anotrichium tenue. Mar Ecol Prog Ser 258: 79-86

Jompa J, McCook LJ (2003b) Coral-algal competition: macroalgae with different properties have different effects on corals. Mar Ecol Prog Ser 258: 87-95

Lewis SM (1986) The role of herbivorous fishes in the organization of a Caribbean reef community. Ecol Monogr 56: 183-200

McClanahan TR, Muthiga NA (1998) An ecological phase shift in a remote coral atoll of Belize over 25 years. Env Conserv 25: 122-130

McManus JW, Polsenberg JF (2004) Coral-algal phase shifts on coral reefs: ecological and environmental aspects. Prog Oceanogr 60: 263-279

Miller RJ, Adams AJ, Ogden NB, Ogden CJ, Ebersole JP (2003) Diadema antillarum 17 years after mass mortality: is recovery beginning on St. Croix? Coral Reefs 22: 181-187

Morrison D (1988) Comparing fish and urchin grazing in shallow and deeper reef algal communities. Ecology 69: 1367-1382

Morrow KM, Carpenter RC (2008) Macroalgal morphology mediates particle capture by the corallimorpharian Corynactis californica. Mar Biol 155: 273-280

Nadon MO, Stirling G (2006) Field and simulation analyses of visual methods for sampling coral cover. Coral Reefs 25: 177-185

Nagle DG, Paul VJ (1998) Chemical defense of a marine cyanobacterial bloom. J Exp Mar Biol Ecol 255: 29-38

Nugues MM, Roberts CM (2003) Coral mortality and interaction with algae in relation to sedimentation. Coral Reefs 22: 507-516

Nugues MM, Smith GW, van Hooidonk RJ, Seabra MI, Bak RPM (2004) Algal contact as a trigger for coral disease. Ecol Let 7: 919-923

Paul VJ, ruz-Rivera, Thacker RW (2001) Chemical mediation of macroalgal-herbivore interactions: ecological and evolutionary perspectives. . In: McClintock JB, Baker BJ (eds) Marine Chemical Ecology. CRC Press, Boca Raton, FL, pp 227-265

Potts DC (1977) Suppression of coral populations by filamentous algae within damselfish territories. J Exp Mar Biol Ecol 28: 207-216

Reinthal PN, Macintyre IG (1994) Spatial and temporal variations in grazing pressure by herbivorous fishes: Tobacco reef, Belize. Atoll Res Bull 425: 1-11

River GF, Edmunds PJ (2001) Mechanisms of interaction between macroalgae and scleractinians on a coral reef in Jamaica. J Exp Mar Biol Ecol 261: 159-172

PeerJ reviewing PDF | (v2014:05:2108:3:0:NEW 5 Aug 2014) 
294

295

296

297

298

299

300

301

302

303

304

305

306

307

308

309

310

311

312
Sandin SA, Smith JE, DeMartini EE, Dinsdale EA, Donner SD, Friedlander AM, Konotchick T, Malay M, Maragos JE, Obura D, Pantos O, Paulay G, Richie M, Rohwer F, Schroeder RE, Walsh S, Jackson JBC, Knowlton N, Sala E (2008) Baselines and degradation of coral reefs in the Northern Line Islands. PloS One 3: e1548

Schmitt TM, Hay ME, Lindquist N (1995) Constraints on chemically mediated coevolution: multiple functions foe seaweed secondary metabolites. Ecology 76: 107-123

Smith JE, Shaw M, Edwards RA, Obura D, Pantos O, Sala E, Sandin SA, Smriga S, Hatay M, Rohwer FL (2006) Indirect effects of algae on coral: algae-mediated, microbe-induced coral mortality. Ecology Letters 9: 835-845

Stevenson C, Katz LS, Micheli F, Block B, Heiman KW, Perle C, Weng K, Dunbar R, Witting J (2007) High apex predator biomass on remote Pacific islands. Coral Reefs 26: 47-51

Stewart JG (1989) Establishment, persistence and dominance of Corallina (Rhodophyta) in algal turf. J Phycol 25: 436-446

Titlyanov EA, Yakovleva IM, Titlyanova TV (2007) Interaction between benthic algae (Lyngbya bouillonii, Dictyota dichotoma) and scleractinian coral Porites lutea in direct contact. J Exp Mar Biol Ecol 342: 282-291

Wild C, Niggl W, Naumann MS, Haas AF (2010) Organic matter release by Red Sea coral reef organisms - potential effects on microbial activity and in-situ $\mathrm{O}_{2}$ availability. Mar Ecol Prog Ser 411: 61-71

\section{FIGURE LEGENDS}

314 Figure 1. Summary of transect sites. The numbers next to dots refer to order of station names

315 (Table 1), along a distance gradient to shore; distance groups: inshore (site 1-4), inner midshore

316 (site 5-8, 13), outer midshore (site 9-10), offshore (site 11-12). 
317 Figure 2. Exemplary photographs of coral-algae contacts observed during the transect surveys;

318 (a) no visible harmful impact of Halimeda sp. on Orbicella sp., (b) overgrowth of Agaricia 319 agaricites by the brown alga Dictyota, (c) overgrowth of Orbicella sp. by filamentous algae, (d) 320 or pigment change of Siderastrea sp. next to red algae.

321 Figure 3. Benthic cover of scleractinian corals and algae along with their contact frequency and 322 D. antillarum abundances (per $100 \mathrm{~m}^{-2}$ seafloor area) at the three reef complexes (Barrier Reef, 323 inshore; Turneffe Atoll, midshore; Lighthouse Reef, offshore) in increasing distance to shore. 324 Values are means $\pm \mathrm{SE}$.

325 Figure 4. Benthic cover of corals and algae, including herbivorous fishes (in ranks) and number 326 of coral-algae contacts in relation to shore distance (measured as relative distance to population 327 centre Belize City). 


\section{Table $\mathbf{1}_{\text {(on next page) }}$}

Table 1

Table 1. Location and characteristics of sampling sites. 
Table 1. Location and characteristics of sampling sites.

\begin{tabular}{cccccc}
\hline Site & Category & Distance & Longitude & Latitude & Water depth \\
& & $(\mathbf{k m})$ & & $(\mathbf{m})$ \\
\hline 1 & inshore & 17 & $17^{\circ} 22.411 \mathrm{~N}$ & $88^{\circ} 4.714 \mathrm{~W}$ & 5 \\
2 & inshore & 19 & $17^{\circ} 21.115 \mathrm{~N}$ & $88^{\circ} 1.730 \mathrm{~W}$ & 6 \\
3 & inshore & 19 & $17^{\circ} 19.499 \mathrm{~N}$ & $88^{\circ} 2.951 \mathrm{~W}$ & 7 \\
4 & inshore & 12 & $17^{\circ} 29.706 \mathrm{~N}$ & $88^{\circ} 02.550 \mathrm{~W}$ & 8 \\
5 & inner midshore & 32 & $17^{\circ} 19.541 \mathrm{~N}$ & $87^{\circ} 57.547 \mathrm{~W}$ & 6 \\
6 & inner midshore & 34 & $17^{\circ} 17.871 \mathrm{~N}$ & $87^{\circ} 57.685 \mathrm{~W}$ & 5 \\
7 & inner midshore & 39 & $17^{\circ} 13.441 \mathrm{~N}$ & $87^{\circ} 56.632 \mathrm{~W}$ & 5 \\
8 & inner midshore & 37 & $17^{\circ} 15.213 \mathrm{~N}$ & $87^{\circ} 57.406 \mathrm{~W}$ & 5 \\
9 & outer midshore & 47 & $17^{\circ} 15.733 \mathrm{~N}$ & $87^{\circ} 49.147 \mathrm{~W}$ & 6 \\
10 & outer midshore & 47 & $17^{\circ} 16.704 \mathrm{~N}$ & $87^{\circ} 48.394 \mathrm{~W}$ & 6 \\
11 & offshore & 70 & $17^{\circ} 13.562 \mathrm{~N}$ & $87^{\circ} 36.104 \mathrm{~W}$ & 6 \\
12 & offshore & 70 & $17^{\circ} 12.891 ' \mathrm{~N}$ & $87^{\circ} 36.475 ' \mathrm{~W}$ & 6 \\
13 & inner midshore & 40 & $17^{\circ} 32.6422^{\prime} \mathrm{N}$ & $87^{\circ} 49.581 ' \mathrm{~W}$ & 7 \\
\hline
\end{tabular}




\section{Table 2 (on next page)}

Table 2

Table 2. Benthic cover and major organisms at the sites of investigation. "Coral-algae contact (\%)" is the relative proportion of corals in direct contact with benthic algae. "Visibly harmful (\%)" illustrates which of these interactions resulted in coral overgrowth or pigmentation change (see Fig. 2b-d). Herbivorous fish (parrot fishes, surgeon fishes and chubs) abundance in the water column up to $3 \mathrm{~m}$ above the surveyed $100 \mathrm{~m}^{2}$ area was estimated using the following categories: few $(n=1-5)$, few-occasional $(n=6-10)$, occasional $(n=11$ $50)$, occasional-many $(n=51-100)$, many $(n>101)$. "N.a." indicates that values are not available. 
Table 2. Benthic cover and major organisms at the sites of investigation. "Coral-algae contact (\%)" is the relative proportion of corals in direct contact with benthic algae. "Visibly harmful (\%)" illustrates which of these interactions resulted in coral overgrowth or pigmentation change (see Fig. 2b-d). Herbivorous fish (parrot fishes, surgeon fishes and chubs) abundance in the water column up to $3 \mathrm{~m}$ above the surveyed $100 \mathrm{~m}^{2}$ area was estimated using the following eategories: few $(n=1-5)$, few-occasional $(n=6-10)$, occasional $(n=11-50)$, occasional-many $(n=51-100)$, many $(n$ > 101). "N.a." indicates that va waves are not available.

\begin{tabular}{|c|c|c|c|c|c|c|c|c|c|c|c|}
\hline Site & $\begin{array}{c}\text { Coral } \\
\text { cover }(\%)\end{array}$ & $\begin{array}{c}\text { Dominant } \\
\text { corals }\end{array}$ & $\begin{array}{c}\text { Algae } \\
(\%)\end{array}$ & $\begin{array}{c}\text { Dominant } \\
\text { algae }\end{array}$ & $\begin{array}{l}\text { Coral-algae } \\
\text { contact (\%) }\end{array}$ & $\begin{array}{c}\text { Visibly } \\
\text { harmful (\%) }\end{array}$ & $\begin{array}{c}\text { Octocoral } \\
(\%)\end{array}$ & $\begin{array}{c}\text { Fire coral } \\
(\%)\end{array}$ & $\begin{array}{c}\text { Sponge } \\
(\%)\end{array}$ & $\begin{array}{c}D . \\
\text { antillarum } \\
\left(\mathrm{n} 100 \mathrm{~m}^{-2}\right)\end{array}$ & $\begin{array}{c}\text { Herbivorous fish } \\
\text { abundance }\end{array}$ \\
\hline 1 & 5 & Agaricia & 20 & Halimeda & 67 & n.a. & 16 & 0 & 12 & 0 & few \\
\hline 2 & 19 & Montastrea & 14 & Halimeda & 41 & 47 & 30 & 4 & 2 & 0 & few \\
\hline 3 & 4 & Montastrea & 39 & Halimeda & 44 & 44 & 10 & 2 & 6 & 0 & occasional \\
\hline 4 & 15 & Montastrea & +3 & Dictyota & 78 & 33 & 14 & 0 & 2 & 0 & occasional \\
\hline 5 & 4 & Montastrea & $(-7)$ & Halimeda & 67 & 33 & 8 & 2 & 5 & 0 & few-occasional \\
\hline 6 & 7 & Agaricia & 2 & Halimeda & 50 & 0 & 13 & 5 & 6 & 0 & occasional \\
\hline 7 & 6 & Agaricia & 45 & Rhipocephalu & 50 & & 2 & 1 & 3 & 0 & occasional \\
\hline & & & & $s$ & & 100 & & & & & \\
\hline 8 & 10 & Siderastrea & 7 & Halimeda & 41 & 43 & 7 & 3 & 8 & 0 & occasional \\
\hline 9 & 19 & Siderastrea & 28 & Dictyota & 22 & 33 & 16 & 2 & 4 & 0 & occasional \\
\hline 10 & 13 & Porites & 27 & Halimeda & 35 & 33 & 12 & 5 & 4 & 0 & few \\
\hline 11 & 29 & Agaricia & 14 & Halimeda & 40 & 50 & 17 & 4 & 7 & 1 & many \\
\hline 12 & 26 & Agaricia & 13 & Dictyota & 21 & 41 & 5 & 2 & 4 & 2 & many \\
\hline 13 & 5 & Porites & 9 & Dictyota & 10 & n.a. & 15 & 1 & 11 & 3 & occasional-many \\
\hline
\end{tabular}




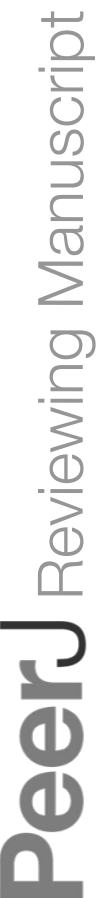

PeerJ reviewing PDF | (v2014:05:2108:3:0:NEW 5 Aug 2014) 


\section{Table 3 (on next page)}

Table 3

Table 3. Correlation of measured parameters with distance to shore. 
Table 3. Correlation of measured parameters with distance to shore.

\begin{tabular}{llccc}
\hline Benthic cover & & $\begin{array}{c}\text { Significan } \\
\text { ce level }\end{array}$ & p & Rsp \\
\hline Corals & $(\%)$ & $(*)$ & 0.046 & 0.508 \\
Algae & $(\%)$ & - & 0.274 & -0.328 \\
Coral-algae-contact & $(\%)$ & $* *$ & 0.001 & -0.810 \\
Octocorallia & $(\%)$ & - & 0.656 & -0.137 \\
Fire corals & $(\%)$ & - & 0.19 & 0.388 \\
Sponges & $(\%)$ & - & 0.814 & 0.072 \\
$\begin{array}{l}\text { D. antillarum } \\
\text { abundance }\end{array}$ & $($ individuals & $*$ & 0.028 & 0.606 \\
Herbivorous fish & $\left(100 \mathrm{~m}^{-2}\right)$ & & & \\
\hline
\end{tabular}




\section{Figure 1}

Figure 1

Figure 1. Summary of transect sites. The numbers next to dots refer to order of station names (Table 1), along a distance gradient to shore; distance groups: inshore (site 1-4), inner midshore (site 5-8,13), outer midshore (site 9-10), offshore (site 11-12). 


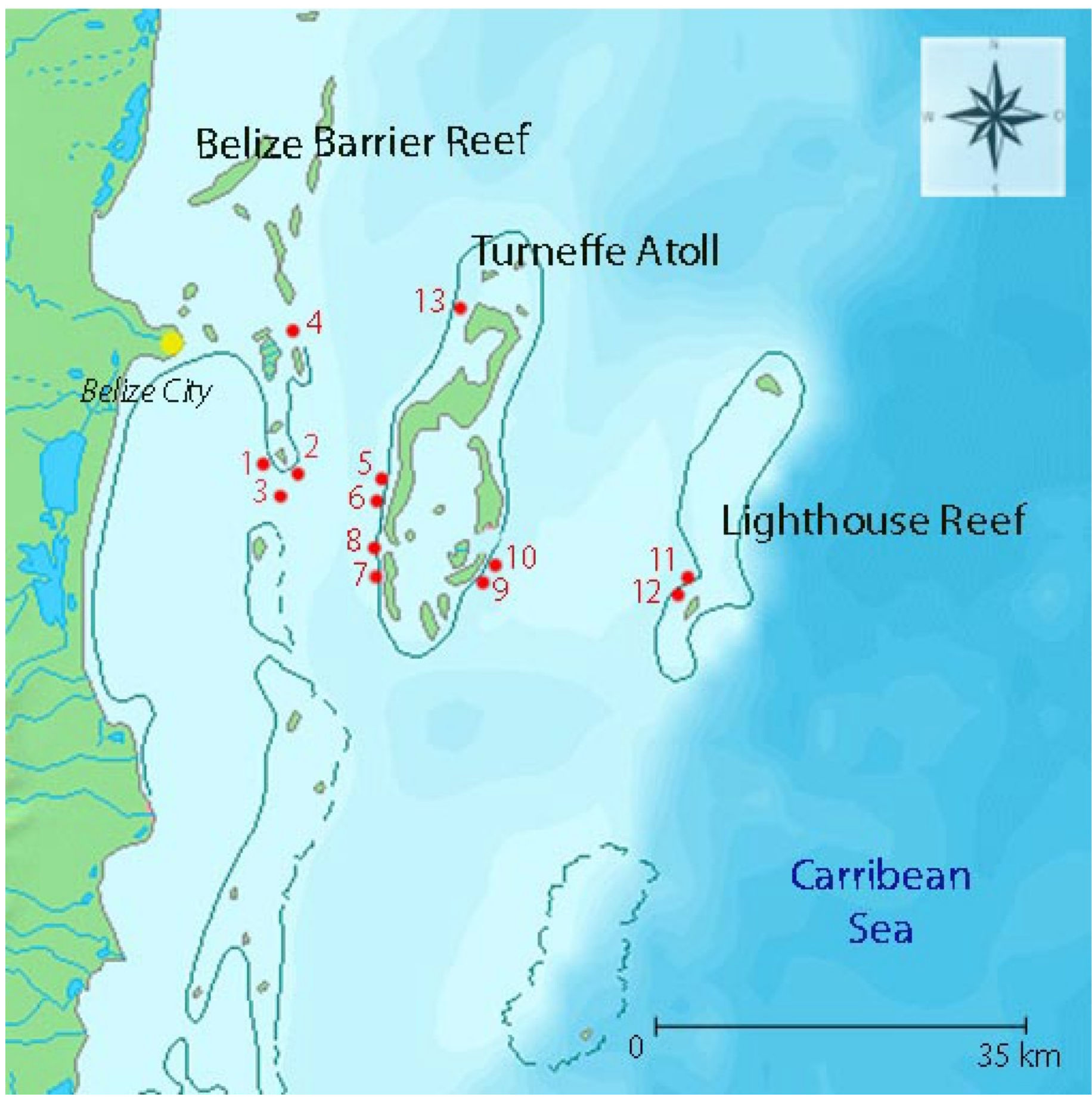




\section{Figure 2}

Figure 2

Figure 2. Exemplary photographs of coral-algae contacts observed during the transect surveys; (a) no visible harmful impact of Halimeda sp. on Orbicella sp., (b) overgrowth of Agaricia agaricites by the brown alga Dictyota, (c) overgrowth of Orbicella sp. by filamentous algae, (d) or pigment change of Siderastrea sp. next to red algae.
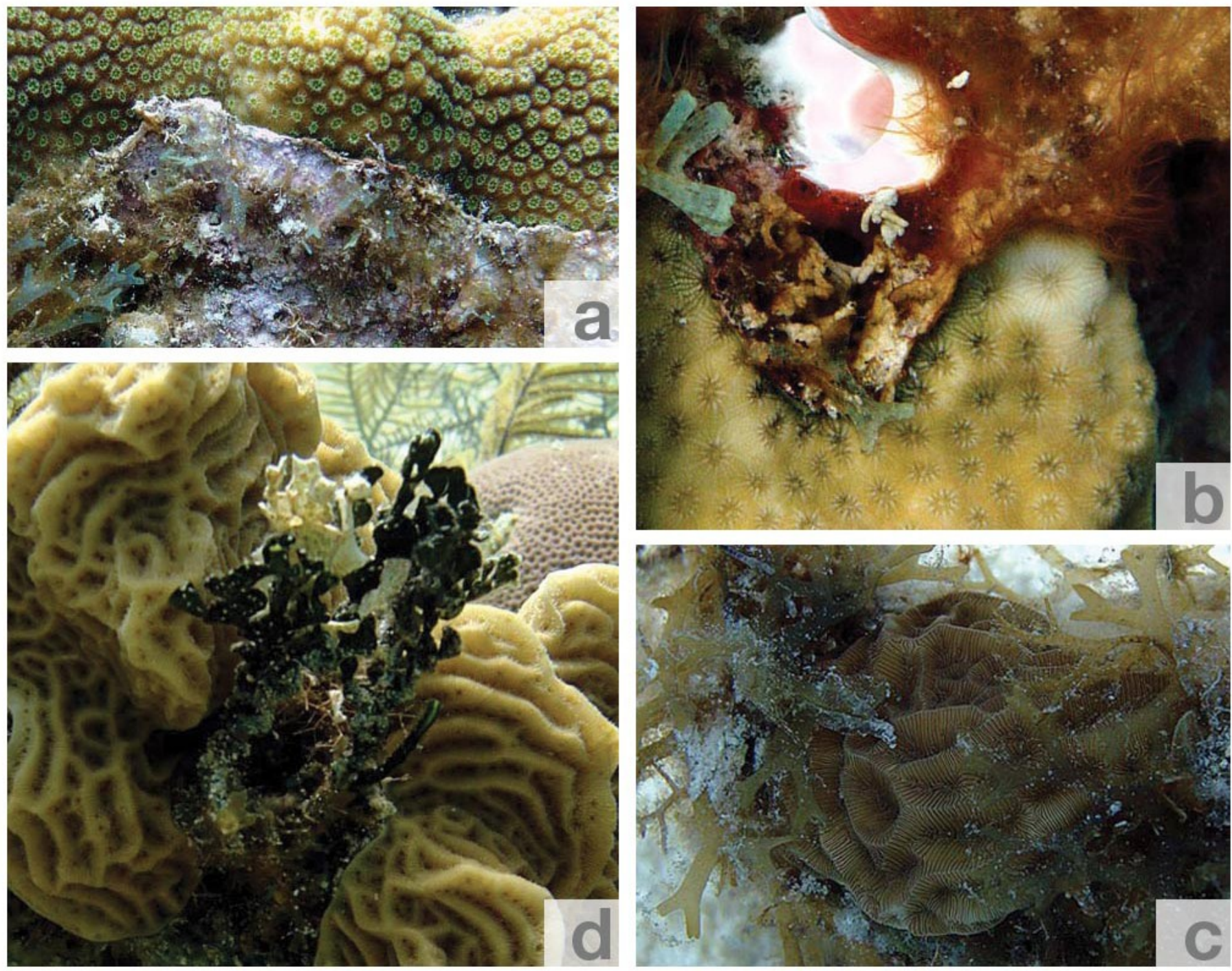


\section{Figure 3}

Figure 3

Figure 3. Benthic cover of scleractinian corals and algae along with their contact frequency and D. antillarum abundances (per $100 \mathrm{~m}-2$ seafloor area) at the three reef complexes (Barrier Reef, inshore; Turneffe Atoll, midshore; Lighthouse Reef, offshore) in increasing distance to shore. Values are means \pm SE. 


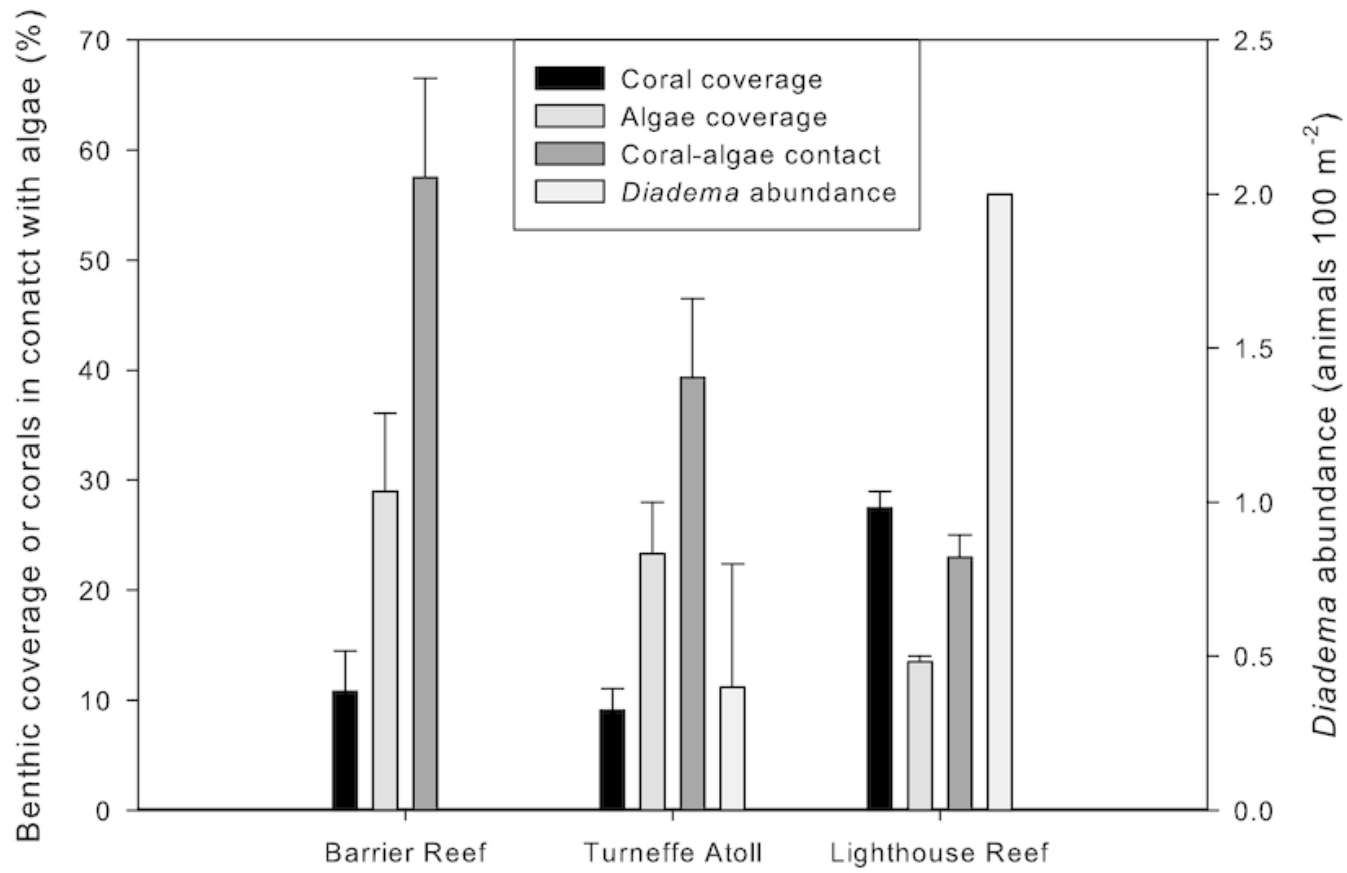




\section{Figure 4}

Figure 4

Figure 4. Benthic cover of corals and algae, including herbivorous fishes (in ranks) and number of coral-algae contacts in relation to shore distance (measured as relative distance to population centre Belize City).

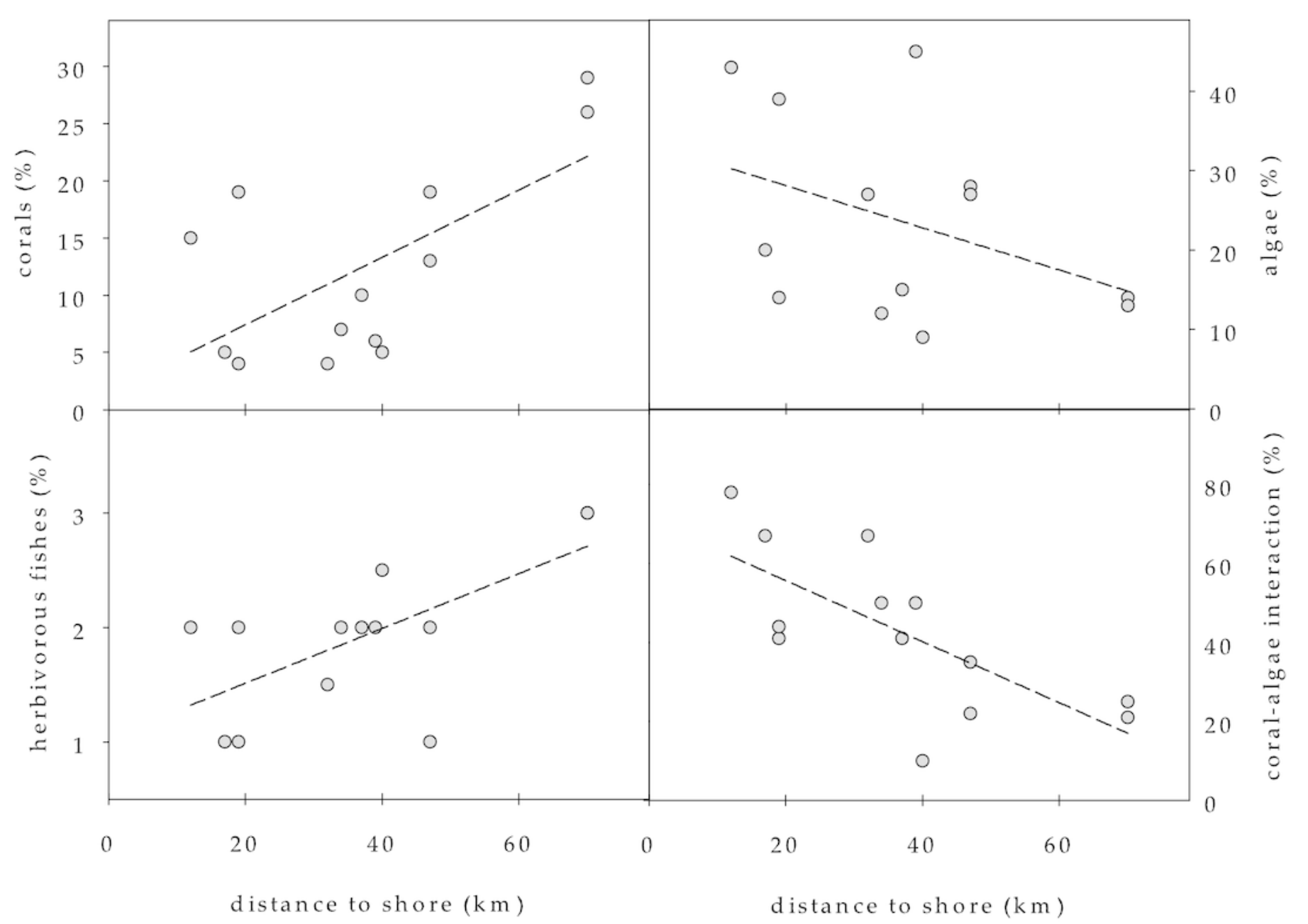

